\title{
$17: 22898282-22968585$
}

National Cancer Institute

\section{Source}

National Cancer Institute. 17:22898282-22968585. NCI Thesaurus. Code C45035.

Physical location of KSR_Gene 